Niepełnosprawność. Dyskursy pedagogiki specjalnej

Agata Jakubas

Uniwersytet Wrocławski

\title{
Obrazy znaczących relacji międzyludzkich kobiet z głębszą niepełnosprawnością intelektualną uczęsz- czających do Środowiskowego Domu Samopomocy
}

\author{
Illustrations of significant interpersonal relations of women \\ with moderate to severe intellectual disability, attending \\ an Environmental Self-Care Institution
}

This article presents selected fragments of an analysis within a wider research project conducted for an unpublished master's thesis. To expose threads relevant for the subject, it focuses on categories of significant interpersonal relations, created by examined women. Each of the analytical aspects was associated with an idea of gender identity, as the essential component of one's social identity. Selection of an individual in-depth interview, as well as techniques of semi-structured interview and qualitative observation allowed to maintain the focus on subjective perception of formed (forming) ties, emotional basis of mentioned interactions and their reflections in individual trajectories. Conclusions outline author's thoughts on some of advantages, as well as risks associated with attending the Environmental Self-Care Institution. The article ends with a personal reflection on some of the perpetuating sociocultural templates - mainly related to the constructs of gender, disability and relations of care-taking/care-giving.

Słowa kluczowe: pedagogika specjalna + funkcjonowanie społeczno-emocjonalne, kobiecość, niepełnosprawność intelektualna, płeć, relacje, środowiskowy dom samopomocy, tożsamość płciowa

Keywords: special education + environmental self-care institution, femininity, gender, gender identity, intellectual disability, relations, socioemotional functioning

\section{Poczucie tożsamości płciowej jako komponent autoidentyfikacji relacyjnej}

Termin „tożsamość” został włączony w obszar zainteresowań nauk społecznych przez Erika Eriksona w latach 50. XX w. Jego pierwotna konceptualizacja wywodzi się z nurtu psychologii rozwojowej i dotyczy integralności osobowej 
osiąganej stopniowo na kolejnych etapach rozwoju psychospołecznego. Do innych ujęć, zyskujących z czasem rosnące uznanie, należą perspektywa poznawcza (definiująca tożsamość jako rodzaj samowiedzy) oraz podejście socjologiczno-kulturowe (opisujące dynamiczny konstrukt społeczny) (Tokarska 2011, s. 40). Zróżnicowane nurty analizy wskazują na znaczenie tożsamości jako podstawy doświadczania odrębności względem pewnych grup społecznych oraz przynależności do innych. Takie połączenie znajduje swój odpowiednik w definicji poczucia tożsamości płciowej. Określa ono relacje pomiędzy subiektywną identyfikacją osoby z określoną kategorią rodzajową oraz ustosunkowaniem do społecznie przypisanych ról płci (por. Jarząbek-Bielecka 2012, s. 70; Nowosielski 2010, s. 93). Negatywne odniesienie do wymienionych aspektów wiąże się z ryzykiem ostracyzmu społecznego oraz poczucia „rodzajowej nieadekwatności” (Kopciewicz 2003, s. 147).

Do osób mogących doświadczyć szczególnych trudności z identyfikowaniem się z powszechnymi kategoriami społecznymi należą kobiety z głębszą niepełnosprawnością intelektualną.

\section{Kobieta z głębszą niepełnosprawnością intelektualną w perspektywie znaczących relacji społecznych}

W literaturze tematycznej zwraca się uwagę, że kobiety przypisane do grupy osób z niepełnosprawnością intelektualną mają styczność z co najmniej trzema rodzajami dyskryminacji stwarzającymi zwielokrotnione ryzyko wiktymizacji. Osoby te mogą doświadczać marginalizacji społecznej, ze względu na: płeć (podobnie jak wszystkie kobiety w różnym zakresie), niepełnosprawność (względem "pełnosprawnej" większości) oraz niepełnosprawność intelektualną (wyznaczającą niską pozycję w stratyfikacji wewnątrzgrupowej osób z niepełnosprawnością). Bywają zatem uznawane za najbardziej zdegradowaną i zarazem najbardziej bezbronną część społeczeństwa, szczególnie narażoną na zróżnicowane formy wyzysku i przemocy (Fitzgerald, Withers 2013, s. 6; Pallaska, Szeli 2004, s. 117). Zagrożenie osoby z głębszą niepełnosprawnością intelektualną może być wzmacniane przez takie cechy, jak: niepełne rozumienie sytuacji społecznych, odczuwanie silnej zależności od innych oraz znaczne deficyty w zakresie wiedzy psychoseksualnej (Fornalik 2010, s. 62). Izolacja edukacyjna i „społeczna niewidzialność" (związana z ograniczeniami w komunikacji, stereotypowym postrzeganiem itp.) przyczyniają się do tego, że wiele kobiet z niepełnosprawnością intelektualną nie potrafi przełamać bezradności lub nie rozpoznaje we właściwym czasie doznawanej krzywdy (Król, Migalska 2012, s. 91). 
Doświadczenia związane z niepełnosprawnością intelektualną nie pozostają bez znaczenia dla rozwoju relacji interpersonalnych - a zatem pola aktywności, w którym większą efektywność przypisuje się kobietom (Rawa-Kochanowska 2011, s. 53). Jak podkreśla Janina Wyczesany, głębsza niepełnosprawność intelektualna nie wyklucza przyswojenia elementarnych norm społecznych oraz reguł związanych z porozumiewaniem się (Wyczesany 2002, s. 38). Zakłócenia kontaktu osoby z otoczeniem (uwarunkowane, między innymi, deficytami poznawczymi lub zaburzeniami integracji sensorycznej) mogą stanowić źródło negatywnych doznań emocjonalnych. Przyczyną szczególnych trudności bywają niepowodzenia w nawiązywaniu i podtrzymywaniu komunikacji ze znaczącymi Innymi.

Mimo wzrostu liczby publikacji poświęcanych tematyce psychoseksualności osób z niepełnosprawnością intelektualną (zob. np. Fornalik 2010; JaniszewskaNieścioruk 2013; Kijak 2014), kwestia inicjowania przez nie trwałych relacji uczuciowych wydaje się podlegać ciągłej tabuizacji. Dorota Krzemińska (2009, s. 95) opisuje praktyki instytucjonalne (w obrębie ośrodków stałej i częściowej opieki) nacechowane protekcjonalnym, pobłażliwym traktowaniem osób z deficytami poznawczymi. Nieokazywanie powagi dorosłym ludziom decydującym o gotowości do związku intymnego oraz koncentracja na kontroli zachowań seksualnych (Lausch-Żuk 2004, s. 78; Jurczyk 2015, s. 231) sugerują trwałość - niedeklarowanego już wprost - zwątpienia kadry specjalistycznej w zdolności osób z niepełnosprawnością intelektualną do tworzenia dojrzałych, obustronnie korzystnych relacji międzyludzkich. Zmianom postaw nie sprzyja kulturowe tworzenie zależności pomiędzy atrakcyjnością wizerunkową a predyspozycjami do doświadczania i wyrażania potrzeb psychoseksualnych (Janiszewska-Nieścioruk 2013, s. 252).

Warto zwrócić uwagę na powiązanie poszczególnych obszarów funkcjonowania kobiety z głębszą niepełnosprawnością intelektualną. Bariery komunikacyjno-społeczne czy fizjonomiczne mogą pogłębiać efekt etykietyzacji (związany $\mathrm{z}$ "naznaczeniem” stygmatem niepełnosprawności lub płci). Wiąże się z tym zjawisko automarginalizacji osoby identyfikującej się ze społecznie wyznaczoną pozycją (Titkow 2007, s. 51). Ograniczenia wyboru realizowanych ról mogą zaś stać się źródłem poczucia bezsilności i doświadczenia "zinternalizowanej opresji” (por. Malhotra, Rowe 2015, s. 159; Darzins 2014, s. 13). Próba przerwania tego „zamkniętego cyklu”(Migalska, Król 2012, s. 20) wydaje się wymagać wcześniejszego poznania grup odniesienia danej osoby oraz wyzwolenia jej aktywności w wyborze własnych identyfikacji. Brak jednak odpowiedzi na pytanie: co z podmiotami, których wykluczenie uniemożliwia branie odpowiedzialności za własny los?

Budowanie sieci znaczących relacji międzyludzkich należy do celów powoływania funkcjonowania placówek wsparcia dziennego (Juros 2010, s. 98). Wśród nich środowiskowy dom samopomocy stanowi szczególne źródło wspar- 
cia dla osób, które nie sa w stanie podołać bardziej wymagajacym i ustrukturyzowanym programom (De Barbaro, Cechnicki, Ostoja-Zawadzka 2005, s. 77). Wspomniane zależności, a także utrzymujący się deficyt tak ukierunkowanych badań, stanowiły inspirację do podjęcia się próby zgłębienia tematu.

\section{Metodologia badań własnych}

We wcześniejszej części artykułu wspomniano o „zamkniętym cyklu”, utrwalanym przez krzyżowanie się obszarów wykluczeń (Król, Migalska 2012, s. 49). Tworzone w jego obrębie ograniczenia mogą wiązać się z barierami w budowaniu znaczących identyfikacji społecznych i intymnych relacji międzyludzkich. Ze względu na odgórne przyjmowanie określonej specyfiki funkcjonowania emocjonalno-społecznego osób z głębszą niepełnosprawnością oraz przetrwały stereotyp „wiecznych dzieci”, szczególnie istotne wydaje się być uznawanie zdolności przedstawicielek owej populacji do prezentowania własnego punktu widzenia.

Niniejsza analiza stanowi część szerszego opracowania badawczego ${ }^{11}$. Tematem prowadzonych wówczas badań było wówczas indywidualne doświadczanie własnej przynależności rodzajowej przez siedem kobiet z orzeczeniami głębszej niepełnosprawności intelektualnej (cztery umiarkowanej oraz trzy znacznej). Osoby badane reprezentowały przedział wiekowy od 25 do 56 lat. Wszystkie respondentki korzystały z usług środowiskowego domu samopomocy. W analizie zebranego materiału wyróżniono wątki samowiedzy i samoświadomości, subiektywnych znaczeń przypisywanych przez badane własnej kobiecości i sobie w roli kobiety oraz specyfikę relacji z reprezentantami obu płci. Mając na uwadze temat niniejszego artykułu, szczególną uwagę poświęcono w nim następującym pytaniom badawczym:

- Jaki jest obraz więzi interpersonalnych tworzonych przez respondentki?

- Jakie znaczenie mają owe relacje dla codziennego funkcjonowania emocjonalno-społecznego kobiet?

Jako fundamenty teoretyczne dla rozstrzygania wyróżnionych zagadnień wybrano podejście interpretatywno-konstruktywistyczne. Ujęcie interpretatywne umożliwia dokonywanie opisu „rzeczywistości wielu perspektyw” (Douglas 1976; za: Malewski 1997, s. 18). Konstruktywizm uzupełnia wgląd w indywidualne sposoby doświadczania rzeczywistości o możliwość poznawania procesów jej „społecznego tworzenia” (Flick 2004, s. 35). Bada zatem relacje międzyludzkie oraz społeczno-kulturowe podłoże ich konstruowania (tamże, s. 36-38). Synteza

1 A. Jakubas, Poczucie tożsamości ptciowej kobiet z głębszą niepetnosprawnościa intelektualną, uczestniczek środowiskowego domu samopomocy, 2015. Praca magisterska, tekst nieopublikowany. 
ujęć interpretatywnego oraz konstruktywistycznego dała tym samym możliwość skupienia się na pewnych uwarunkowaniach marginalizacji i automarginalizacji jednostek ",naznaczonych” - w sposób szczególny stygmatem przynależności do kategorii niepełnosprawności oraz płci (Benton, Craib 2003, s. 188).

W próbie odpowiedzi na postawione pytania posłużono się metodą indywidualnego wywiadu pogłębionego oraz technikami częściowo ustrukturyzowanego wywiadu i obserwacji bezpośredniej, przynależącymi do strategii badań jakościowych. W nawiązywaniu kontaktu z osobami z obniżoną sprawnością językową wykorzystano również elementy komunikacji alternatywnej i wspomagającej (piktogramy i ilustracje). Wybrane instrumentarium badawcze sprzyjało podtrzymywaniu głównego wątku tematycznego, przy jednoczesnym zachowaniu „wrażliwości kontekstowej” (Flick 2010, s. 137). Uwzględnienie analizy obserwacji służyło pogłębieniu wglądu w każdy z indywidualnych przypadków, w powiązaniu z szerszym kontekstem (Bauman, Pilch 2001, s. 87; Łobocki 2001, s. 218). Zebrane w ten sposób informacje umożliwiły wyłonienie kategorii opisu odpowiadających konkretnym sytuacjom poszczególnych kobiet. Wzięto pod uwagę między innymi postawy (wskaźniki behawioralne i emocjonalne) zaobserwowane podczas omawiania kwestii związanych z aspektami roli płciowej i relacjami interpersonalnymi oraz ich spójność z komunikatami słownymi. Uwzględniono także opis wybranych interakcji badanych $\mathrm{z}$ osobami płci przeciwnej i tożsamej.

Ze względu na temat artykułu, poniżej połączono wątki analityczne uznane za szczególnie istotne dla zobrazowania sfery funkcjonowania emocjonalnospołecznego osób badanych.

\section{Znaczące relacje społeczne $\mathrm{w}$ perspektywach kobiet $\mathrm{z}$ głębszą niepełnosprawnością intelektualną - analiza wyników badań własnych}

Tożsamość płciowa budowana jest $\mathrm{w}$ oparciu o modele ról pełnionych przez znaczących reprezentantów obu płci. Dorastający człowiek aktywnie angażuje się $\mathrm{w}$ przyswajanie standardów zachowań obserwowanych u przedstawicieli własnego rodzaju, zachowując dystans wobec wzorów kojarzonych z odmienną płcią (Rawa-Kochanowska 2011, s. 26). W przypadku osób z głębszą niepełnosprawnością intelektualną, dla których system rodzinny stanowi nie tylko pierwotne, ale także trwałe podłoże codziennego funkcjonowania, wczesne modele pozostają niekiedy dominującymi. Z taką sytuacją wiąże się długotrwały brak dostępu do innych znaczących wzorów, również $\mathrm{w}$ zakresie budowania intymnych relacji w diadzie partnerskiej (Marszałek 2006, s. 194). Zgodnie z opisaną tendencją, 
wszystkie respondentki zamieszkiwały środowiska rodzinne, pozostając pod opieką rodziców (niekiedy z czynnym udziałem rodzeństwa). Badane spędzały jednak znaczną część dnia w środowisku różnym od rodzinnego. Jak zatem wyglądała specyfika funkcjonowania kobiet w relacjach interpersonalnych?

Oprócz środowiska rodzinnego większość badanych ograniczała bliskie kontakty z reprezentantkami własnej płci do relacji podtrzymywanych w Środowiskowym Domu Samopomocy. Jedyną osobą przełamującą tę prawidłowość okazała się być Anna², która (jakby zgodnie z zasadą alternatywnego wyboru) nie stworzyła w Ośrodku więzi uznawanych przez siebie za istotne:

Przyjaźni tu dla mnie nie ma. No jasne, tu nie jest źle, dobrze jest na tych zajęciach. (...). Zazdroszczą tego Kamila mojego. I zazdroszczą, bo ja potrafię dbać o mnie. I tak generalnie... I niech się śmieją. (...) Kobiety, tak samo, nie bardzo, by tą buzię otworzyć. (...). Oni są niedojrzali, jak nie wiem... No, ale oni nie wiedzą, no, co wiedzą, skąd.

Co istotne, respondentka zaakceptowała opisane wyobcowanie, uznając je za konsekwencję zazdrości „niedojrzałych” współuczestników.

Oparcie znajdowane w osobie opisywanej jako „mądra” (z bogatym doświadczeniem życiowym) lub funkcjonującej na wyższym poziomie poznawczym bądź społecznym stało się natomiast wątkiem łączącym narracje respondentek z umiarkowaną niepełnosprawnością intelektualną. Znajoma kobieta z rodzinnej miejscowości Anny oraz współuczestniczki zajęć Ośrodka wymienione przez pozostałe rozmówczynie zostały włączone w szczególnie cenione kontakty rówieśnicze. Zaakcentowano budowanie szczególnych płaszczyzn wzajemnego zrozumienia (swoistego siostrzeństwa emocjonalnego) i wspólne spędzanie wolnego czasu (na spacerach, oglądaniu seriali lub udziale w imprezach kulturalnych). Przyjazny, zażyły kontakt okazał się naturalnym czynnikiem regulującym sytuacyjne napięcie emocjonalne oraz pobudzającym do przyjmowania pozytywnych postaw życiowych. Jak ujęła tę zależność Daria:

Na tym śniadanku rozmowy różne. I tak se żartujemy często-gęsto. Na Kamilkę mówię Kamiluś. Mów na mnie Kamilka, a ja do niej Kamiluś, bo Kamiluś, to coś jest... W ogóle, żartujemy, to żarty takie. Jak smutek - żarty, jeden, drugi i od razu aparatka.

Podkreślono przy tym wartość nie tylko otrzymywania wsparcia, ale także jego udzielania, dającego poczucie akceptacji i użyteczności. Niektóre wypowiedzi wskazały bezpośrednio na pewną wspólnotę doświadczania:

No, to ważne jest, przyjaciółki-kobietki mieć. A gadamy, plotkujemy, tu w czymś pomagam im, no, one to lubią [...]. No, nareszcie sobie z kobietką jak z kobietką, myślę, pogadam. Kobieta, to jak ja, podobnie ma, widzi. A widzi, co tam siedzi [ze wskazaniem na głowę].

$\overline{2}$ Imiona uczestniczek badania zostały zmienione. 
Analizując tożsamość budowaną w relacjach międzyludzkich, nie sposób pominąć wpływu wzorów opozycyjnych - właściwych „Innych". Znaczenie własnego ustosunkowania do płci przeciwnej wzrasta zazwyczaj w okresie adolescencji. Zmiany wiążą się nie tylko z rozwojem sfery psychoseksualnej, ale także dynamiką procesów autodefinicyjnych (Bee 2004, s. 277). Osoby z głębszą niepełnosprawnością intelektualną nie stanowią w tym zakresie wyjątku (Kijak 2011, s. 217).

Aktualne zainteresowanie płcią przeciwną zostało natomiast zdecydowanie wykluczone przez dwie respondentki - Katarzynę oraz Darię. Osobiste doświadczenia badanych sugerują jednak nieco odmienne uwarunkowania tych deklaracji. Pozycja podopiecznej, poddawanej stałej kontroli rodzicielskiej, może kolidować $\mathrm{z}$ podjęciem roli w relacjach partnerskich typowych dla dorosłego człowieka. Katarzyna wskazała na źródło własnego braku poczucia swobody w wypowiedzi dotyczącej spędzania czasu poza Ośrodkiem: [rodzice] „nie pozwolili właśnie. I tak dużo czasu tam przesiaduję w Ośrodku, to po co masz po kątach odbijać jeszcze".

Strategie wychowawcze oraz niedostateczna efektywność oddziaływań specjalistycznych mogły przyczynić się do rezygnacji kobiety z uczestnictwa w zajęciach wychowania do życia w rodzinie. Katarzyna (zaprezentowana przez psychologa jako „buntowniczka funkcjonująca najwyżej na poziomie dwunastolatki") sprawiała wrażenie poprawnie zasymilowanej w grupie koedukacyjnej. Podczas rozmowy wyznała natomiast, że marzenia o satysfakcjonującym związku i rodzicielstwie są częścią jej planów życiowych - nie określiła jednak czasu ich realizacji. Wszystkie deklaracje odnosily się do "poczucia niepewności losu” (Pisula 2008, s. 20; Tylewska-Nowak 2001, s. 25):

Jak tak szczerze, to pewnie, że chciałabym dziecko, rodzinę, dziecko, męża. Nie będę kryć w sekrecie, że marzenie mam, jak każda kobieta... Ale to każda kobieta, właśnie. Ja, to... Ja to dzisiaj nie. Jutro. Dzisiaj nie [...].

Odmienne motywacje mogły wiązać się z działaniami opiekunów Darii. Odraczanie pełnienia ról właściwych etapowi dorosłości wydawało się mieć w tym przypadku klarowne przyczyny - kobieta $\mathrm{z}$ genetycznie uwarunkowaną bezpłodnością (rzadka konfiguracja niepełnosprawności intelektualnej z zespołem Turnera) nie wyda przecież na świat potomstwa. Wykluczono również perspektywę adopcji, z uwagi na orzeczenie głębszej niepełnosprawności intelektualnej. W ramach swego rodzaju rekompensaty środowisko rodzinne zaoferowało kobiecie pełnienie zastępczych zadań opiekuńczych nad bratankiem. Oczywiście, była to rola epizodyczna i fakultatywna, ale przecież w tej sytuacji trudno wyobrazić sobie bardziej "dogodny” układ (nie wspominając o jego realizacji). Z utratą perspektywy macierzyństwa współwystępowało oczekiwanie rezygnacji $\mathrm{z}$ bycia żoną (czy szerzej - partnerką). Daria adaptowała się do tej sytuacji, uz- 
nając, że jest: „w ogóle z innej bajki. Chłopacy to inne epoki. To... [gest odtrącania] «Odejdź, karalne»".

Jako oznakę tego zdystansowania można uznać zachowawczy, lakoniczny sposób komunikowania się Ewy z przedstawicielami płci przeciwnej. Możliwe zagrożenie dla efektywności obranej strategii pojawiło się natomiast w innym kontekście, podczas wypowiedzi o rodzeństwie: „Brata mam. Taką siostrę. Nie lubimy się, jak ten pies z kotem (...). Wyprowadził się akurat. Karolka wzięli. W ogóle go nie mam".

Jak przekonywali pracownicy Domu, energiczność (przejawiająca się m.in. zaangażowaniem w organizację imprez rozrywkowych) oraz opiekuńczość Darii sprawiły, że badana jest generalnie lubiana przez pozostałych uczestników. Co istotne, według słów samej respondentki: „na razie nic nie jest więcej potrzebne”. Druga cecha wydawała się być jednak na tyle istotną częścią tożsamości badanej, że perspektywa rozłąki z głównym obiektem realizacji potrzeb rodzicielskich (bratankiem) stanowiła nacechowany emocjonalnie i wielokrotnie podejmowany wątek rozmowy.

Przykłady znacząco odmiennych relacji ujawniły kolejne badane, funkcjonujące w diadach partnerskich. Dramatyczna przeszłość Kamili (doświadczanie przemocy i śmierci ojca) oraz realia (alkoholizm opiekunki) nie wydawały się stanowić czynników determinujących jakość aktualnej egzystencji badanej. Indywidualistyczne usposobienie, ujawniana potrzeba osiągnięć oraz „zmysł praktyczny" mogły predysponować respondentkę do dobrego funkcjonowania na stanowisku wiceredaktora ośrodkowej gazety. Cechy te prawdopodobnie przyczyniły się także do niedawnego zainicjowania związku ze współuczestnikiem zajęć. Czynna postawa, satysfakcjonujące stosunki z innymi kobietami oraz związek intymny sugerują, że respondentka wypracowała efektywne strategie radzenia sobie z trudnościami życiowymi. Aktywność okazała się być również istotną kategorią opisu własnej roli w relacji z mężczyzną. Stanowczość to cecha pożądana w związku, ponieważ:

No, chłopów ogarnąć trzeba (...). Jak kobieta zaradna jest, i chłopa-, mężczyznę sobie wychowa, tak. No, mężczyzna też pracować musi, myślę. No, a romantyczny być. A kobietce dogadzywać. Ale ja pilnować muszę.

Warto wspomnieć, że układ ten prezentował rodzaj "białego małżeństwa” (Grütz 2011, s. 184), nieaspirującego aktualnie do poszerzania rodziny. Respondentka argumentowała to w następujący sposób:

No, pierw trzeba dużo normalnego życia douczyć. (...) Jakoś sobie z życiem tym radzić. A daleko mieszkać i daleko pracować - od wsi, od domu tu. A... potem to może tak. Może i nie. No ja tak mam. 
Można opisać tę sytuację jako w pewien sposób analogiczną do narracji Katarzyny. Perspektywa warunkowa wydawała się jednak łączyć ze świadomym odroczeniem przez Kamilę ewentualnego rodzicielstwa i dążeniem do bliższego celu - usamodzielnienia. Udane partnerstwo mogłoby ułatwić jego osiągnięcie, a zatem warto wziąć za nie odpowiedzialność.

Pozory radykalnie odmiennej roli w związku z mężczyzną stwarza przykład Anny. Podejście respondentki do więzi intymnej wydawało się potwierdzać tezę o silniejszym doznawaniu przez kobiety z niepełnosprawnością potrzeb poczucia bezpieczeństwa i akceptacji (Marszałek 2006, s. 105). Także udział w zajęciach usamodzielniających został odniesiony do wspólnej aktywności - mimo partnera niebędącego beneficjentem Ośrodka: „Uczymy się dbać o domy. Co tam dobrego przypichcić z Tomaszem, by nam dobrze było razem. Ale ja to lubię bardzo, no oczywiście".

Brak osobistego poczucia niezależności nie wydawał się natomiast spójny ze znaczeniem przypisywanym przez rozmówczynię tożsamości kobiety, która: "może robić, co się chce. Co się chce, jasne. By tylko w domu za późno [nie być]”. Potrzebę stałego dostępu do bliskiego, partnerskiego oparcia połączono zatem z uświadomioną i zaakceptowaną niepełnosprawnością:

Krótko będzie, to będę... to ja jestem [osobą z niepełnosprawnością]! (...) Mężczyznę potrzebuję i potrzebuję, by tu przychodzić. [Inne kobiety] Nie, one nie potrzebują jak niepełnosprytne. Jak one chcą mieć, to mają, ale nie... nie potrzebują (...).

Własny stygmat został przedstawiony przez Annę jako powód doświadczania szczególnej potrzeby współbycia. Równolegle podkreślono natomiast, że kobieta „nienaznaczona” etykietą nie musi spełniać podobnego warunku. Dla samej rozmówczyni związek wydawał się stanowićjeden $\mathrm{z}$ fundamentów poczucia osobistej wartości oraz źródło siły w zmaganiach $\mathrm{z}$ „poczuciem samotności w niepełnosprawności" (Speck, 1996, s. 20). Miał także znaczenie w budowaniu identyfikacji z inną osobą znaczącą - przyjaciółką, która (w przeciwieństwie do "niedojrzałych" znajomych) nie bywa zazdrosna, ponieważ: „(...) ma jeszcze-, już nie-chłopaka. Już męża. (...) Chłopaków mamy fajnych i my jesteśmy fajne. Karolina jest mądra dla mnie". Świadomość własnego stygmatu może również stanowić dodatkowe zaplecze wewnętrznej siły i determinacji. Wszak rozmówczyni jest: „(...) kobietą. A trzeba znać, kto się jest”.

$\mathrm{W}$ odniesieniu do powyższych wypowiedzi, pewne różnice znamionowały sytuacje społeczne respondentek ze znaczną niepełnosprawnością intelektualną. Obserwowana w Środowiskowym Domu Samopomocy aktywność przedstawicielek tej grupy stwarzała wrażenie swobodnego "dryfowania” - w dużej mierze samotnego wykonywania zadań zleconych przez pracowników Ośrodka lub spacerowania, przerywanego okazyjnym kontaktem z terapeutami i (rzadziej) inny- 
mi uczestnikami zajęć. Do dominujących wzorów należały milcząca współobecność (Danuta) oraz czynne zabieganie o aprobatę ze strony opiekunów (Sylwia, Zofia). Przykłady ostatniego przywodziły niekiedy na myśl pojęcie "lepkości emocjonalnej", opisywane przez Małgorzatę Kościelską (2004, s. 35).

Obciążenia chorobowe nie stanowiły dla Sylwii przeszkody przed regularnym uczestniczeniem $w$ zajęciach grupowych. Sprawiała wrażenie osoby dynamicznej, co (w założeniu) mogłoby nie sprzyjać utrzymywaniu uwagi na wykonywanych czynnościach. Ograniczenia aktywności zajęciowej do angażowania się $\mathrm{w}$ najprostsze ćwiczenia zostały przypisane przez terapeutę zajęciowego postawie podopiecznej, która "nie wykazuje chęci nauczenia się czegoś nowego". Jedną z cech charakteryzujących tę badaną było natomiast podejmowanie zachowań unikowych w sytuacjach odczuwanych jako kłopotliwe. W relacji innego pracownika właśnie praktyki ucieczek stały się przyczyną odsuwania Sylwii od niektórych „niekomfortowych” zajęć, do których należała część treningu samoobsługi, a także wychowanie do życia w rodzinie. Do grona znaczących Innych badana włączyła ojca („Jasia”) oraz inną postać płci męskiej, wyjaśnianą przez kadrę ŚDS-u jako reprezentację „wymyślonego" brata. Znamiennym wydaje się być w tym kontekście definiowanie kobiety (czy też „laski”) przez pryzmat posiadania "chłopa". Mężczyzna był osobą najbliższą respondentce, jednak temat relacji intymnych w odniesieniu osobistym okazał się nieprzekraczalnym tabu (do stopnia wskazującego, że próba jego wznowienia może prowadzić do nagłej ucieczki $\mathrm{z}$ miejsca wywiadu).

Zofia, dla której nie prognozowano początkowo żadnych zauważalnych postępów, została przedstawiona jako jedna z najbardziej towarzyskich uczestniczek zajęć. Jak się jednak okazało, entuzjazm ten nie znalazł przełożenia na ośrodkową frekwencję - obecność badanej pozostała okazjonalna i naznaczona niską aktywnością zajęciową. Taki tryb funkcjonowania oraz cykliczne epizody zachowań agresywnych nie ułatwiały nawiązania trwałych więzi grupowych. Jako jedyną „przyjaciółkę" Zofia wyróżniła imiennie jedną z terapeutek. Nie zaobserwowano także oznak preferowania przez badaną spędzania czasu w towarzystwie osób określonej płci - przy wyraźnej tendencji do koncentrowania na sobie uwagi prowadzących zajęcia.

Podczas naszego spotkania respondentka ujawniła natomiast wzmożone zainteresowanie kontekstem męskiej nagości. Odpowiednie ilustracje wzbudziły u Zofii aprobatę, której ruchowe manifestacje (energiczne gesty oraz rozentuzjazmowana mimika) odznaczały się szczególną dynamicznością. Psycholog poinformował mnie również o „prawie zażegnanych trudnościach" badanej z publicznym obnażaniem się i masturbacją, co powiązano z doświadczeniem przemocy seksualnej. Zachowania seksualne zostały zatem wyjaśnione jako efekt przeżytej traumy, a ich pojawianie się - jako rodzaj reakcji na kumulację frustracji. Strategie 
zaradcze kadry specjalistycznej ukierunkowano na wygaszanie „kłopotliwych” aktywności przez ich kierowanie na inne działania lub (w, jak zaznaczono, „mniej drastycznych przypadkach”) sytuacyjne odseparowanie Zofii („zapewnianie intymności"). Na tej podstawie nie sposób oczywiście dokonywać choćby pobieżnej oceny zarysowanych praktyk (co nie jest także celem analizy). W świetle obserwowanych reakcji respondentki oraz różnorodności potrzeb emocjonalnych wymienianych jako możliwe źródła publicznej autostymulacji (Kościelska 2004, s. 44), zastanawiać może jednotorowość ich interpretowania.

$\mathrm{Na}$ atrybutach korzystnych $\mathrm{w}$ funkcjonowaniu społecznym oparto także prezentację Danuty: pracownicy i współuczestnicy opisali osobę wyciszoną, cieszącą się ogólną sympatią. Sama respondentka, zapytana o relacje z innymi kobietami, potwierdziła niejako ten stan: „Lubię. Wszystkie lubię". Podobne stosunki zostały ponadto określone jako istotne, ponieważ: „(...) to koleżanki moje”. Pytanie o kontakty z "kolegami” wydawało się natomiast prowadzić do natychmiastowych skojarzeń z relacjami intymnymi. Badana stwierdziła z determinacją nietowarzyszącą żadnej innej wypowiedzi, że: „Nawet nie myślę... o tym. Nawet o tym nie myślę jeszcze".

Podczas obserwacji odnotowano znikomą ilość czasu spędzanego przez badaną $w$ towarzystwie mężczyzn, co powiązano początkowo z dyspozycjami osobowymi. Wątek ustosunkowania respondentki do męskiej społeczności Ośrodka został jednak podjęty przez terapeutę zajęciowego, twierdzącego, iż obcowanie $\mathrm{z}$ "chłopakami” wpływa na Danutę „rozleniwiająco". Uwaga ta okazała się legitymizować w przeszłości próby ograniczenia zbytniego „spoufalania się", np. przez włączanie do zajęć odpowiednio wyselekcjonowanej grupy. Ze względu na kontekst przebytych stanów psychotycznych konieczne było doprecyzowanie przez pracownika, że nie chodziło o nadmiernie ekspansywne zachowania, ale o skłonności Danuty do „fantazjowania” i „głośnych" rozmów. Historia uczestnictwa badanej w zajęciach dostarczyła więc informacji o tym, że w istocie Danuta okazuje (a przynajmniej okazywała) zainteresowanie kontaktami międzypłciowymi, zaś na ich obecny kształt nie pozostały bez wpływu środowiskowe strategie „normalizacyjne".

\section{Próba podsumowania}

Powyższe treści stwarzają pewne pole do dyskusji o programie wspomagania kobiet z głębszą niepełnosprawnością intelektualną w wybranej placówce. Przestrzeń instytucjonalna daje asumpt do samorozwoju oraz poszerzania więzi społecznych osobom nierzadko pozbawionym znaczących kontaktów pozarodzinnych. $Z$ drugiej strony kompensacyjne podłoże niektórych z opisanych rela- 
cji może wskazywać na ograniczenia niektórych kierunków ich rozwoju - szczególnie $\mathrm{w}$ zakresie budowania więzi intymnych oraz adekwatnego obrazu własnych możliwości.

W ramach Środowiskowego Domu Samopomocy podejmuje się starania o realizację zasady partnerstwa. Służy temu podział kompetencji z uwzględnieniem zróżnicowania indywidualnych predyspozycji. Instytucja wydaje się również sprzyjać nawiązywaniu znajomości społecznych. Równocześnie aktywne jest jednak piętno (używając sformułowania Jolanty Lausch-Żuk) postawy protekcjonalnej, dostrzegalne w sposób szczególny wobec reprezentantek grupy badawczej. Jej konkretne przykłady obejmują stosowanie sformułowań dyrektywnych oraz podtrzymywanie "infantylizujących" form wzmocnień (Lausch-Żuk 2004, s. 423). Treść i warstwa formalna języka kontaktów społecznych wpływają natomiast na rozwój psychomocjonalny, a w efekcie - samą tożsamość płciową oraz definiowanie własnej pozycji w relacjach (Kościelska 2000, s. 6).

Warto zwrócić uwagę, że żadna z rozmówczyń z diagnozą niepełnosprawności intelektualnej stopnia znacznego (podobnie jak większość z niepełnosprawnością umiarkowaną) nie brała udziału w zajęciach wychowania do życia w rodzinie. Rolę pewnej alternatywy spełniała propozycja treningów kosmetyczno-higienicznych. Ćwiczenia, którym nie sposób odmówić walorów motywacyjnych i funkcjonalnych, w zakresie tożsamości płciowej przyczyniają się do rozwoju przede wszystkim powierzchownych jej aspektów. Podtrzymywanie "miękkiej” infantylizacji może natomiast stać się czynnikiem niesprzyjającym rozwijaniu innych wyznaczników samoświadomości i budowaniu trwałych, intymnych więzi - nawet jeśli przyświecają temu szczytne idee normalizacji „od podstaw” (Kościelska 2004, s. 66).

Według Lidii Marszałek (2006, s. 160), pragnienie pełnienia tradycyjnych ról może stać się formą sprzeciwu wobec zastanych ograniczeń środowiskowych. Małgorzata Prokosz wskazuje, że rolę czynnika terapeutycznego, niwelującego „kryzys płciowości", pełni niekiedy rodzicielstwo (2009, s. 271). Bez względu więc na to, czy stanowi ono wyraz źródłowej potrzeby, czy też przystosowania do oczekiwań społecznych, macierzyństwo pojawiło się w większości narracji, a osobiste ustosunkowanie do tematyki odzwierciedlało sytuacje życiowe badanych. Znamiennym wydaje się być fakt, że wątek został wyeksponowany przez kobietę świadomą własnej bezpłodności. Warto zgłębić kwestię innych powiązań sytuacyjnych, niełączących się już bezpośrednio ze stanem fizycznym (np. wykluczania perspektywy relacji intymnych).

Wbrew powielanym fobiom społecznym, Carline Frohmader i Helen Meekosha wyjaśniają, że wyniki badań podważają istotność diagnozy niepełnosprawności intelektualnej jako predykatora jakości rodzicielstwa i partnerstwa (2010, s. 10; za: Migalska, Król 2012, s. 85). Eksploracje empiryczne Joanny Kruk-Lasockiej 
wskazują na istotne znaczenie terapeutyczne zaangażowania we współopiekę nad potomstwem oraz trwałe relacje intymne dla osób z głębszą niepełnosprawnością intelektualną (Kruk-Lasocka 2005; za: Janiszewska-Nieścioruk 2013, s. 262). Jednym $\mathrm{z}$ bardziej sensownych rozwiązań ( $w$ znaczeniu funkcjonalnym i etycznym) wydają się być instytucje małżeństwa chronionego oraz wspomaganego rodzicielstwa. Nieinwazyjna pomoc przeszkolonych asystentów i współopiekunów daje możliwości wspierania autonomii z poszanowaniem potrzeb intymności oraz rodzicielstwa (tamże, s. 263). Modele te wymagają jednak znacznego rozpowszechnienia i pokonania bariery uprzedzeń, także (a może przede wszystkim) na poziomie działań instytucjonalnych. Rozdźwięk pomiędzy „deklaratywną poprawnością" oraz „praktycznym dyscyplinowaniem” wydaje się kierować ku potrzebie ujawniania stereotypów przetrwałych w postawach samych decydentów (Jurczyk 2015, s. 227).

Otwierane pola refleksji nad płcią i niepełnosprawnością inspirują dyskusje, w których mogłyby wziąć udział grupy dotychczas z nich wyłączone. Dostrzeżenie tej szansy umożliwiałoby propagowanie aktywnych postaw w przeciwdziałaniu marginalizacji i (w efekcie) automarginalizacji. Przewartościowanie kulturowych wzorów relacji międzypłciowych oraz założeń na temat funkcjonowania emocjonalnego osób z niepełnosprawnością intelektualną sugeruje, że wspieranie człowieka dorosłego w osiąganiu pełnego potencjału dojrzałości osobowej, bez należytego respektowania jednostkowych doświadczeń i tożsamości, jest działaniem z założenia nieefektywnym.

Jaki zatem okazał się obraz znaczących relacji społecznych oraz ich wpływu na funkcjonowanie psychoemocjonalne badanych kobiet? Truizmem byłoby stwierdzenie, że na podobnie sformułowane pytanie nie sposób udzielić odpowiedzi innej, niż: złożony. Znaczenia przypisywane (osobistej) kobiecości obejmowały nie tylko dbałość o budowanie własnego wizerunku i aktywne podtrzymywanie więzi społecznych, ale także umiejętności świadczenia opieki i wsparcia. Co istotne, każde z powyższych wydawało się stanowić istotny element budowania pozytywnej oceny ego. Ukazane powiązania mogłyby przemawiać na korzyść tezy Raviego Malhotry i Morgana Rowe’a o fikcyjności dychotomii „opiekujący (się)-opiekowany" - nieaktualnej lub nigdy nie prawdziwej - oraz komplementarności potrzeb emocjonalnych leżących u podstaw obu funkcji (Malhotra, Rowe 2015, s. 172).

Aby wykroczyć poza kazuistykę skrótowych refleksji, może warto pójść dalej $\mathrm{w}$ kierunku rozwoju kameralnych koncepcji praktyki, których przedmiotem byłoby tworzenie i współtworzenie własnych "małych teorii" (Żółkowska 2011, s. 90). Za zasadnością tej propozycji mogłyby przemawiać umiejętności oraz wola respondentek do dzielenia się własnymi doświadczeniami - z pozycji dorosłej, określonej płciowo osoby. 


\section{Bibliografia}

Barbaro de B., Cechnicki A., Ostoja-Zawadzka K. (2005), Możesz pomóc. Poradnik dla rodzin pacjentów chorych na schizofrenię, Wydawnictwo Uniwersytetu Jagiellońskiego, Kraków.

Bauman T., Pilch T. (2001), Zasady badań pedagogicznych. Strategie ilościowe i jakościowe, Wydawnictwo Akademickie „Żak”, Warszawa.

Bee H. (2004). Psychologia rozwojowa, Wydawnictwo Zysk i Spółka, Poznań.

Benton T., Craib I. (2003), Filozofia nauk społecznych. Od pozytywizmu do postmodernizmu, Wydawnictwo Dolnośląskiej Szkoły Wyższej Edukacji TWP, Wrocław.

Darzins A. (2014), Domestic violence and women with disabilities: neglected problem, „Berkley Undergraduate Journal", vol. 27(2).

Fitzgerald C., Withers P. (2013), "I don't know what a proper woman means": what women with intellectual disabilities think about sex, sexuality and themselves, „British Journal of Learning Disabilities", no. 41.

Fornalik I. (2010), Dojrzewanie. Miłość. Seks. Poradnik dla rodziców osób z niepetnosprawnościa intelektualna, Stowarzyszenie Rodzin i Opiekunów Osób z Zespołem Downa Bardziej Kochani, Warszawa.

Frohmader C., Meekosha H. (2012), Recognition, Respect and Rights: Women With Disabilities in a Globalised World [w:] Disability and Social Theory, red. B. Hughes; L. Davis, Palgrave Macmillan, Houndmills.

Grütz M. (2011), Osoby z niepetnosprawnością intelektualna jako partnerzy, matżonkowie i rodzice [w:] Dorośli z niepetnosprawnościq intelektualnq w labiryntach codzienności, red. B. Cytowska, Wydawnictwo Adam Marszałek, Torun.

Janiszewska-Nieścioruk Z. (2013), Respektowanie i egzekwowanie praw seksualnych osób z niepetnosprawnościq - palący, nierozwiązany problem [w:] Człowiek z niepetnosprawnościa w rezerwacie przestrzeni publicznej, red. Z. Gajdzica, Oficyna Wydawnicza „Impuls”, Kraków.

Jarząbek-Bielecka G. (2012), Nauka o płci-zagadnienia wybrane, Wydawnictwo Uniwersytetu Medycznego, Poznań.

Jurczyk M. (2015), Nie(petno)normatywna seksualność i (nie)uświadomiona władza. Seksualność niepetnosprawnych intelektualnie w kontekście pytania o emancypację [w:] Codzienność, performatywność, demokracja. Pedagogika wobec norm życiowych i problematyki nienormatywności, red. L. Kopciewicz, B. Simlat-Żuk, Wydawnictwo Naukowe Katedra, Gdańsk.

Kopciewicz L. (2003), Polityka kobiecości jako pedagogika różnic, Oficyna Wydawnicza „Impuls", Kraków.

Kościelska M. (2000), Być kobieta, być mężczyznq - co to znaczy w odniesieniu do osób niepetnosprawnych intelektualnie, „Nowiny Psychologiczne”, nr 2.

Kościelska M. (2004), Niechciana seksualność. O ludzkich potrzebach osób niepetnosprawnych intelektualnie, Wydawnictwo Jacek Santorski \& Co., Warszawa.

Krzemińska D. (2009), O byciu parą osób z niepetnosprawnością intelektualnq, „Niepełnosprawność. Półrocznik Naukowy", nr 2.

Kumaniecka-Wiśniewska A. (2006), Kim Jestem? Tożsamość Kobiet Upośledzonych Umystowo, Wydawnictwo Akademickie Żak, Warszawa.

Lew-Starowicz Z., Skrzypulec V. (2010), Podstawy seksuologii, Wydawnictwo Lekarskie PZWL, Warszawa. 
Łobocki M. (2001), Wprowadzenie do metodologii badań pedagogicznych, Oficyna Wydawnicza „Impuls”, Kraków.

Malewski M. (1997), Metody jakościowe i ilościowe w badaniach nad edukacja. Spór o metodologiczną komplementarność, „Kultura i Edukacja”, nr 1-2.

Malhotra R., Rowe M. (2015), Exploring Disability Identity and Disability Rights through Narratives: Finding a Voice of Their Own, Routledge, Nowy Jork-Londyn.

Marszałek L. (2006), Niepetnosprawność, kobiecość, rodzina, Wydawnictwo Uniwersytetu Kardynała Stefana Wyszyńskiego, Warszawa.

Miluska J. (1996), Tożsamość kobiet i mężczyzn w cyklu życia, Wydawnictwo Uniwersytetu Adama Mickiewicza, Poznań.

Pallaska D., Szeli E. (2004), Violence against women with mental disabilities: The Invisible Victims in CEE/NIS Countries, „Feminist Review”, no. 76.

Rawa-Kochanowska A. (2011), Poczucie tożsamości ptciowej w teorii i badaniach, Wydawnictwo Engram, Warszawa.

Szalast A. (2012), Osoby z niepetnosprawnościa intelektualną w ośrodku wsparcia dziennego, „Niepełnosprawność i Rehabilitacja".

Titkow A. (2007), Tożsamość polskich kobiet: ciagłość, zmiana, konteksty, Wydawnictwo Instytutu Filozofii i Socjologii PAN, Warszawa.

Tokarska U. (2011), Tożsamość narracyjna w dobie płynnej nowoczesności. Nowe wyzwania dla psychologii narracyjnej [w:] Pejzaże tożsamości. Teoria i empiria w perspektywie interdyscyplinarnej, red. E. Litak, R. Furman, H. Brożek, Wydawnictwo Uniwersytetu Jagiellońskiego, Kraków.

Tylewska-Nowak B. (2001), Autonomia osób z głębszą niepetnosprawnością intelektualną w opinii wybranych grup spolecznych, Wydawnictwo Naukowe Uniwersytetu Adama Mickiewicza, Poznań.

Wyczesany J. (2002), Pedagogika upośledzonych umystowo. Wybrane zagadnienia, Oficyna Wydawnicza „Impuls”, Kraków.

Żółkowska T. (2011), Normalizacja - niedokończona teoria pedagogiki specjalnej, „Niepełnosprawność. Półrocznik naukowy", nr 5.

\section{Źródła internetowe}

Król A., Migalska A., Diagnoza i dobre praktyki dotyczące polityk włączania do głównego nurtu życia społecznego kobiet $i$ dziewcząt z niepetnosprawnościami. Doświadczenia międzynarodowe (raport własny), Kraków 2012, http://www.academia.edu/2952691/Diagnoza_i_dobre_praktyki_dotycz\%C4\%85ce_polityk_w\%C5\%82\%C4\%85czania_do_g\%C5\% 82\% C3\%B3wnego_nurtu_\%C5\%BCycia_spo\%C5\%82ecznego_kobiet_i_dziewcz\%C4\%85t z_niepe \%C5\% 82nosprawno\%C5\%9Bciami._Do\%C5\%9Bwiadczenia_mi\%C4\%99dzynarodowe [dostęp: 12.05.2014]. 